\title{
Hubungan Kekerabatan Fenetik Lycopersicon esculentum Mill. Kultivar Betavila F1, Fortuna F1 dan Tymoti F1 Berdasarkan Tingkat Kesamaan Fenotip
}

\author{
The Fenetik Relationship Lycopersicon esculentum Mill. Cultivars Betavila F1, Fortuna F1 \\ and F1 Tymoti Based Similarity Level Phenotype \\ Muhammad Thoifur Ibnu Fajar*, Purnomo, dan Niken Satuti Nur Handayani \\ Fakultas Biologi Universitas Gadjah Mada Yogyakarta \\ Jl. Teknika Selatan, Sekip Utara, Yogyakarta 55281, Indonesia. \\ Email: ibnu4040@gmail.com *Penulis korespondensi
}

\begin{abstract}
The purpose of this study to determine the fenetik relationship of three tomato cultivars Betavila F1, Fortuna F1 and Tymoti F1 through approach phenotype character leaves, flowers, and fruit. Samples were taken from greenhouse at Situbondo. Parts of plants that observed consist of 42 characters, including leaf shape, the shape of petals, flower color, fruit shape, the color of the young fruit, transitional and mature. Data scoring phenotype characters were analyzed with Jaccard coefficient using MVSP program. The result of dendogram divided into four clusters with $36 \%$ similarity index. Fenetik relationship showed Fortuna F1 cultivars is closely related with Tymoti F1 cultivars and Betavila F1 cultivars do not form kinship fenetik because own a distinctive character qualitative. Uniformity of the phenotype of the three cultivars are expected to develop the cultivation of tomatoes by crossing using excels phenotype characters.
\end{abstract}

Keywords: Phenotype, tomato 'Betavila F1,' 'Fortuna F1', 'Tymoti F1', dendrogram

Abstrak

Tujuan penelitian ini untuk menentukan hubungan kekerabatan fenetik ketiga kultivar tomat Betavila F1, Fortuna F1 dan Tymoti F1 melalui pendekatan fenotip daun, bunga, dan buah. Sampel penelitian diambil dari greenhouse Situbondo. Bagian tanaman yang diamati terdiri dari 42 karakter, meliputi bentuk daun, bentuk mahkota bunga, warna mahkota bunga, bentuk buah, warna buah muda, transisi dan matang. Data skoring karakter fenotip dianalisis dengan Jaccard coefficient menggunakan software MVSP. Hasil dendogram dibagi menjadi empat klaster dengan indeks similaritas 36\%. Hubungan kekerabatan fenetik menunjukkan kultivar Fortuna F1 berkerabat dekat dengan kultivar Tymoti F1 dan kultivar Betavila F1 tidak membentuk hubungan kekerabatan fenetik karena memiliki karakter kualitatif yang berbeda. Keseragaman fenotip ketiga kultivar tomat diharapkan untuk mengembangkan budidaya tomat melalui persilangan menggunakan karakter fenotipe yang unggul.

Kata Kunci : Fenotip, Tomat 'Betavila F1,' 'Fortuna F1', 'Tymoti F1', dendogram

Diterima: 10 Maret 2016, disetujui: 3 Mei 2016

\section{Pendahuluan}

Karakter fenotip adalah suatu karakteristik, baik struktural, biokimiawi, fisiologis maupun perilaku yang dapat diamati dari suatu organisme yang diatur oleh genotipe, lingkungan dan interaksi keduanya (Nilahayati dan Putri, 2015). Pengamatan karakter fenotip tanaman terbagi menjadi karakter kualitatif dan karakter kuantitatif. Karakter kualitatif adalah karakter yang diamati didasarkan atas pedoman gambar fenotip dan diwujudkan dalam bentuk skor angka, sedangkan karakter kuantitatif adalah karakter-karakter yang diamati melalui penghitungan atau pengukuran (Sofiari dan Kirana, 2009). Sampel penelitian yang digunakan dalam penelitian ini adalah kultivar Betavila F1, Fortuna F1 dan Tymoti F1 karena ketiga kultivar tomat ini memiliki daya tahan 
yang kuat terhadap serangan hama karena apabila terjadi serangan hama hanya mengenai pada bagian beberapa helai daun seperti daun menjadi keriting dan tidak mengenai pada bagian buah serta masa umur panen yang singkat sehingga dapat mengurangi kendala penelitian pengamatan karakter fenotip dan cocok dijadikan sebagai tanaman model dengan masa umur panen yang singkat (Anonymous, 2006; Anonymous, 2011; Anonymous, 2015).

Penelitian yang dilakukan pada tomat sering terfokus pada budidaya tomat melalui sistem budidaya hidroponik (Wasonowati, 2011), aplikasi pupuk hayati terhadap produktivitas tanaman tomat (Astari dkk., 2014), uji daya hasil tomat pada dataran rendah (Putri dkk., 2014), dataran medium (Purwati, 2009), dataran tinggi (Soedomo, 2012) budidaya tomat melalui pengembangan pemuliaan tanaman dari karakterisasi kromosom (Darmawan, 2010) dan mutasi buatan terhadap genotip tomat pada kondisi lingkungan yang berbeda (Hartati, 2000). Pada penelitian sebelumnya pola hubungan kemiripan fenotip pada varietas tomat digunakan sebagai dasar dalam rekomendasi tetua yang akan dipilih pada pembentukan populasi studi pewarisan (Wahyuni dkk., 2014). Penelitian hubungan kekerabatan fenetik di antara kultivar tomat dipandang perlu, karena dapat diperoleh informasi kedekatan hubungan di antara kultivar tomat berdasarkan persamaan karakter fenotip yang berguna budidaya tomat unggul dari hasil persilangan karakter fenotip yang unggul. Menurut Hasanuddin dan Fitriana
(2014), kesamaan karakter fenotip yang sama menunjukkan kedekatan hubungan kekerabatan secara fenotipe dan perbedaan besar karakter fenotip menunjukkan hubungan kekerabatan fenotip yang jauh. Oleh karena itu, perlu dilakukan penelitian mengenai hubungan kekerabatan fenetik di antara kultivar tomat berdasarkan pendekatan fenotip yang berguna untuk pemuliaaan tanaman tomat unggul.

\section{Metode Penelitian}

Penelitian ini dilakukan di greenhouse Situbondo selama tiga bulan mulai bulan Desember 2015 sampai Februari 2016. Sampel tomat yang digunakan adalah kultivar Betavila F1, Fortuna F1 dan Tymoti F1. Alat-alat yang digunakan dalam penelitian ini adalah roll meter (ESSEN), jangka sorong (VERNIER CALIPER), timbangan analitik portabel (Camry EHA 401), dan kamera digital (Canon IXUS 145). Bagian yang diamati adalah karakter fenotip kualitatif terdiri dari daun, bunga, dan buah. Penelitian ini terbagi menjadi tahapan persiapan penanaman, pengamatan dan pendataan karakter menjadi data skoring karakter morfologi, dan pengolahan data menggunakan program MVSP (Multi- Variate Statistical Package) dengan Jaccard coeficient. Aksesi kultivar tomat yang digunakan dalam penelitian ini seperti pada Tabel 1 .

Tabel 1. Aksesi Kultivar Tomat

\begin{tabular}{|c|c|c|c|c|}
\hline No & Nama Kultivar & Aksesi & "Keterangan & $\begin{array}{l}\text { Hasil Persilangan dan Merek } \\
\text { Kultivar }\end{array}$ \\
\hline 1 & Betavila F1 & $\begin{array}{l}\mathrm{B} 1, \mathrm{~B} 2, \mathrm{~B} 3, \mathrm{~B} 4, \mathrm{~B} 5, \\
\mathrm{~B} 6, \mathrm{~B} 7, \mathrm{~B} 8, \mathrm{~B} 9, \mathrm{~B} 10\end{array}$ & $\begin{array}{l}\text { Pengambilan sampel di } \\
\text { Greenhouse Situbondo dan } \\
\text { habitat dibudidayakan }\end{array}$ & $\begin{array}{l}\text { hasil silsilah antara kedua jenis } \\
\text { tomat dengan kode perusahaan Dee } \\
\text { Max } 53218 \text { x Dee Max } 51106 . \\
\text { Merek : panah merah }\end{array}$ \\
\hline 2 & Fortuna F1 & $\begin{array}{l}\text { F1, F2, F3, F4, F5, F6, } \\
\text { F7, F8, F9, F10 }\end{array}$ & $\begin{array}{l}\text { Pengambilan sampel di } \\
\text { Greenhouse Situbondo dan } \\
\text { habitat dibudidayakan }\end{array}$ & $\begin{array}{l}\text { hasil dari silsilah persilangan tomat } \\
\text { dengan kode perusahaan BTM } \\
2645 \text { A x BTM } 2645 \text { B. } \\
\text { Merek : kapal terbang }\end{array}$ \\
\hline 3 & Tymoti F1 & $\begin{array}{l}\text { T1, T2, T3, T4, T5, T6, } \\
\text { T7, T8, T9, T10 }\end{array}$ & $\begin{array}{l}\text { Pengambilan sampel di } \\
\text { Greenhouse Situbondo dan } \\
\text { habitat dibudidayakan }\end{array}$ & $\begin{array}{l}\text { hasil silsilah persilangan antara } \\
\text { tomat dengan kode perusahaan TO- } \\
58746 \text { x TO- } 62876 \\
\text { Merek : panah merah }\end{array}$ \\
\hline
\end{tabular}




\section{Parameter pengamatan karakter fenotip Daun}

Pengamatan bentuk daun menggunakan pedoman IPGRI (Anonymous, 2015).

\section{Bunga}

Pengamatan bentuk mahkota dan warna mahkota bunga berdasarkan referensi ketiga kultivar tomat (Anonymous, 2006; Anonymous, 2011; Anonymous, 2015) dan daftar warna (Anonymous, 2015).

\section{Buah}

Pengamatan bentuk buah menggunakan pedoman IPGRI dan referensi bentuk buah (Anonymous 3, 2015; Visa dkk., 2014) dan warna buah menggunakan pedoman daftar warna (Anonymous, 2015).

Pemberian nilai angka terhadap 42 karakter tomat dilakukan berdasarkan deskriptor tomat (Anonymous, 2015). Karakter yang diamati yaitu karakter kualitatif. Pengamatan karakter kualitatif didasarkan atas pedoman gambar fenotip karena karakter kualitatif merupakan karakter yang tidak dapat diukur, fenotip yang berbeda antara satu dengan yang lain dan masing-masing dapat dikelompokkan dalam bentuk kategori (Suryo, 2004; Mustofa dkk., 2013). Data skor multistate untuk mendapatkan data biner berupa angka 0 dan 1 dalam bentuk Tabel 2 skoring karakter morfologi kualitatif (Sari, 2015). Data dianalisis dengan analisis klaster. Analisis klaster dilakukan dengan metode UPGMA (Unweighted Pair Group Methods using Arithmetic averages) dengan koefisien korelasi Jaccard Coefficient menggunakan software MVSP v.3.1 (Multivariate Statistical Program) untuk mendapatkan dendogram tersaji pada Gambar 1 (Dalirsefat dkk., 2009).

\section{Hasil dan Pembahasan}

Hasil perbandingan karakter kualitatif ketiga kultivar tomat yang terdiri dari daun, bunga dan buah tersaji pada Tabel 1 dan Gambar 1.

Berdasarkan deskripsi fenotip kualitatif ketiga kultivar tomat tersebut, karakter kualitatif yang beragam terdapat pada organ bentuk daun yaitu bentuk daun standar, hirsutum, dan kerdil, warna mahkota bunga kuning muda dan kuning, bentuk buah bulat, persegi panjang dan hati, warna buah muda hijau keputihan dan hijau muda. Karakter kualitatif merupakan karakter yang perkembangannya dikendalikan DNA dan hampir tidak dipengaruhi lingkungan sehingga menghasilkan fenotip yang khas (Baihaki, 2000 dalam Wanda dkk., 2014).

Hubungan kekerabatan fenetik ketiga kultivar tomat dapat dilihat pada Gambar 2. Dendogram (Gambar 2) yang terbagi menjadi 4 kelompok menunjukkan nilai kesamaan 0,36 (36\%). Dendogram tersebut terbagi menjadi empat kelompok yaitu kelompok I beranggotakan B9 memiliki nilai kesamaan $0,36 \%(36 \%)$ kelompok II beranggotakan B2 dan B3 memiliki nilai kesamaan fenotipe 0,75\% (75\%), kelompok III beranggotakan B5, B6, dan B7 dengan nilai kesamaan fenotipe 0,55\% (55\%) dan anggota B5 dan B7 membentuk kelompok monofiletik dengan nilai kesamaan $100 \%$, serta kelompok IV beranggotakan B1, B4, B8, B10, F1, F2, F3, F4, F5, F6, F7, F8, F9, F10, T1, T2, T3, T4, T5, T6, T7, T8, T9, dan T10 dengan nilai similaritas $0,56(56 \%)$.

Kelompok IV terbagi menjadi dua subkelompok yaitu subkelompok IVa beranggotakan F6 dan F10 yang memiliki nilai kesamaan $0,75(75 \%)$ dan subkelompok IVb beranggotakan B1, B4, B8, B10, F1, F2, F3, F4, F5, F7, F8, F9, T1, T2, T3, T4, T5, T6, T7, T8, T9, dan T10 yang menunjukkan nilai kesamaan $0,57(57 \%)$. Subkelompok IVb terdapat lima anggota yang membentuk kelompok monofiletik, di antaranya kelompok $\mathrm{IVb}_{1}$ terdiri dari F8, T2, T3, dan T8, kelompok $\mathrm{IVb}_{2}$ terdiri dari F2, F3, dan T5, kelompok $\mathrm{IVb}_{3}$ terdiri dari F1, T6, T7, dan T10, kelompok $\mathrm{IVb}_{4}$ terdiri dari F7, T1, T4, dan T9 dan kelompok $\mathrm{IVb}_{5}$ terdiri dari B1, B4, B8, dan B10. Kelima kelompok monofiletik tersebut memiliki nilai similaritas $100 \%$ yang berarti terdapat kemiripan yang sangat tinggi di antara kultivar tersebut.

Berdasarkan dendogram tersebut hubungan kekerabatan fenetik dapat ditemukan pada kelompok IV, kultivar Fortuna F1 berkerabat dekat dengan kultivar Tymoti Fl dan kultivar Betavila F1 tidak membentuk hubungan kekerabatan fenetik dengan kultivar Fortuna Fl 
atau kultivar Tymoti Fl yang disebabkan kultivar Betavila F1 memiliki karakter kualitatif khas yang tidak dimiliki oleh kultivar Fortuna F1 dan kultivar Tymoti F1.

Perbedaan karakter fenotip dalam satu kultivar dan kesamaan karakter fenotip dalam satu kultivar atau kultivar satu dengan kultivar lain dapat disebabkan kondisi lingkungan yang mempengaruhi pertumbuhan dan perkembangan organ pada tumbuhan. Hal ini diperkuat pernyataan Campbell dkk., (2008), adanya evolusi secara konvergen yang terjadi ketika tekanan-tekanan lingkungan yang mirip dan seleksi alam menghasilkan adaptasi yang mirip pada organisme-organisme dari garis keturunan evolusioner yang berbeda-beda sehingga menyebabkan bentuk fenotip yang mirip.

Hubungan kekerabatan dapat digunakan untuk menduga tingkat kesamaan antar spesies atau populasi. Semakin banyak karakter yang dimiliki bersama di antara individu yang dibandingkan, maka semakin dekat hubungan kekerabatan, dan berlaku pula dengan sedikitnya kesamaan karakter yang dimiliki bersama, maka hubungan kekerabatan semakin jauh (Suratman dkk., 2000). Kelebihan kekerabatan secara fenotip koleksi sampel organisme yang banyak di bumi dan tidak membutuhkan biaya penelitian yang mahal (Hillis, 1987). Menurut Donoghue (2008), rekontruksi pohon kekerabatan secara fenotipe atau berdasarkan karakter morfologi tidak dapat menggambarkan hubungan kekerabatan secara obyektif karena menimbulkan homoplasy karakter morfologi yang disebabkan oleh faktor lingkungan.

Studi sebelumnya, keseragaman karakter fenotip yang unggul dari tomat varietas Gadjah Mada 1 dan Gadjah Mada 3 sebagai tetua yang disilangkan dengan tomat Gondol Putih dan Gondol Hijau dapat menghasilkan galur tomat baru yang unggul (Maulida dkk., 2013). Akhirnya, kehadiran keseragaman karakter fenotip pada ketiga kultivar tomat lokal tersebut diharapkan dapat digunakan sebagai pemuliaan tanaman dengan menyilangkan karakter fenotip yang unggul.

Tabel 1. Perbandingan karakter kualitatif ketiga kultivar tomat

\begin{tabular}{|c|c|c|c|}
\hline \multirow[t]{2}{*}{ Parameter } & \multicolumn{3}{|c|}{ Kultivar } \\
\hline & Betavila & Fortuna & Tymoti \\
\hline $\begin{array}{l}\text { Daun } \\
\text { Bunga }\end{array}$ & $\begin{array}{l}\text { Standar, hirsutum dan kerdil } \\
\text { bentuk mahkota bunga, bunga } \\
\text { pertama membuka dengan petal } \\
\text { terlipat. } \\
\text { Warna mahkota bunga kuning dan } \\
\text { kuning muda }\end{array}$ & \begin{tabular}{l}
\multicolumn{2}{l}{ Standar dan hirsutum } \\
bentuk mahkota bunga, \\
bunga pertama membuka \\
dengan petal terlipat. \\
Warna mahkota bunga \\
kuning dan kuning muda
\end{tabular} & $\begin{array}{l}\text { Standar } \\
\text { bentuk mahkota bunga, } \\
\text { bunga pertama membuka } \\
\text { dengan petal terlipat. } \\
\text { Warna mahkota bunga } \\
\text { kuning }\end{array}$ \\
\hline Buah & $\begin{array}{l}\text { Bentuk buah bulat, persegi panjang } \\
\text { dan hati }\end{array}$ & $\begin{array}{l}\text { Bentuk buah bulat dan } \\
\text { persegi panjang }\end{array}$ & Bentuk buah bulat \\
\hline & Warna buah muda hijau keputihan & $\begin{array}{l}\text { Warna buah muda hijau } \\
\text { muda }\end{array}$ & $\begin{array}{l}\text { Warna buah muda hijau } \\
\text { muda }\end{array}$ \\
\hline & $\begin{array}{l}\text { Warna buah transisi jingga, jingga } \\
\text { tua, kuning, dan kuning emas }\end{array}$ & $\begin{array}{l}\text { jingga, jingga tua, kuning, } \\
\text { dan kuning emas }\end{array}$ & $\begin{array}{l}\text { jingga, jingga tua, kuning, } \\
\text { dan kuning emas }\end{array}$ \\
\hline & Warna buah matang merah & Warna buah matang merah & Warna buah matang merah \\
\hline
\end{tabular}




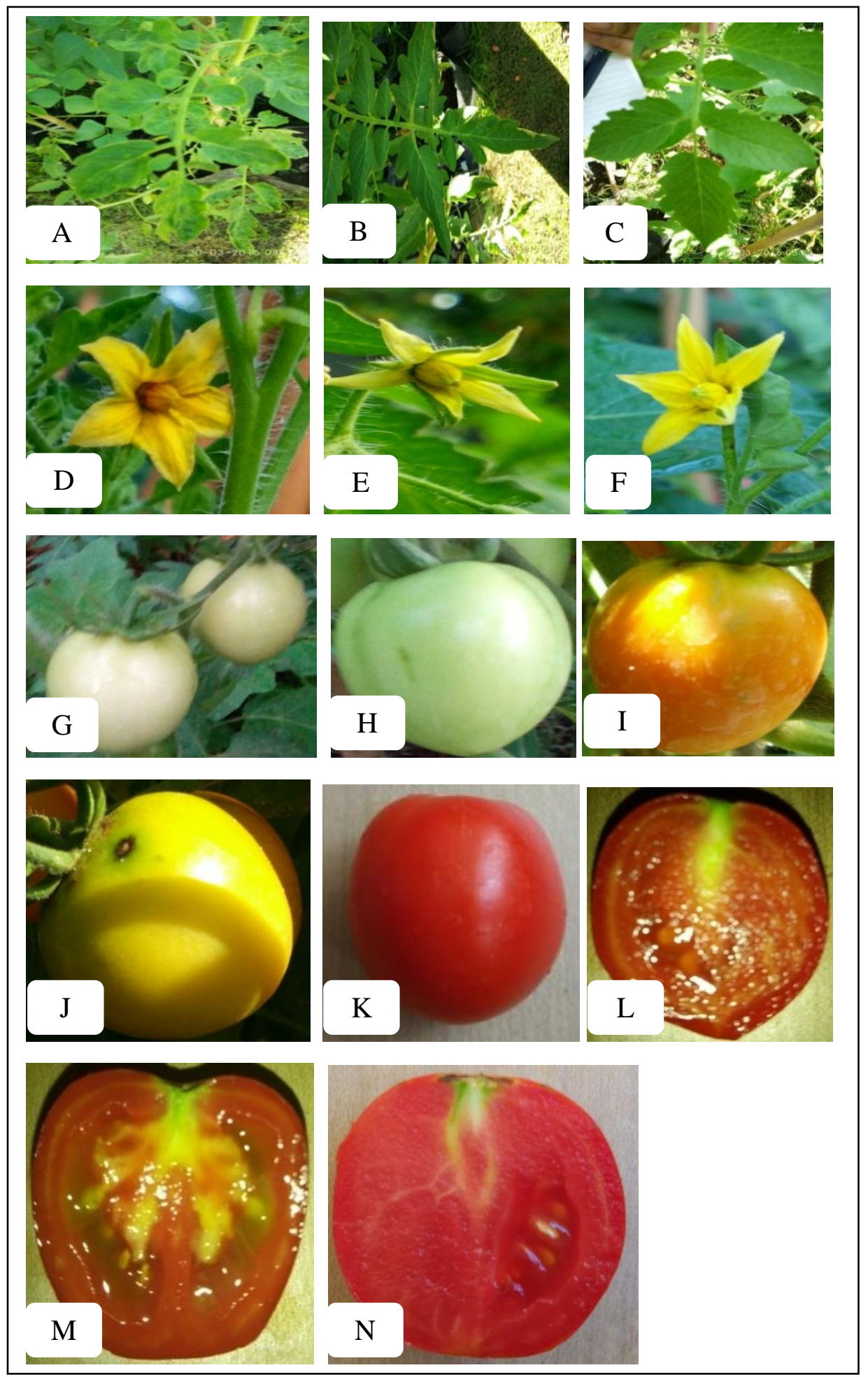

Gambar 1. Morfologi buah. A. Bentuk daun kerdil. B. Bentuk daun hirsutum. C. Bentuk daun standar. D. Warna mahkota kuning. E. Warna mahkota kuning muda. F. Warna mahkota kuning. G. Warna buah muda hijau keputihan. H. Warna buah muda hjau muda. I. Warna buah transisi jinggga. J. Warna buah transisi kuning. K. Warna buah matang merah. L. Bentuk buah hati. M. Bentuk buah persegi panjang. N. Bentuk buah bulat. 


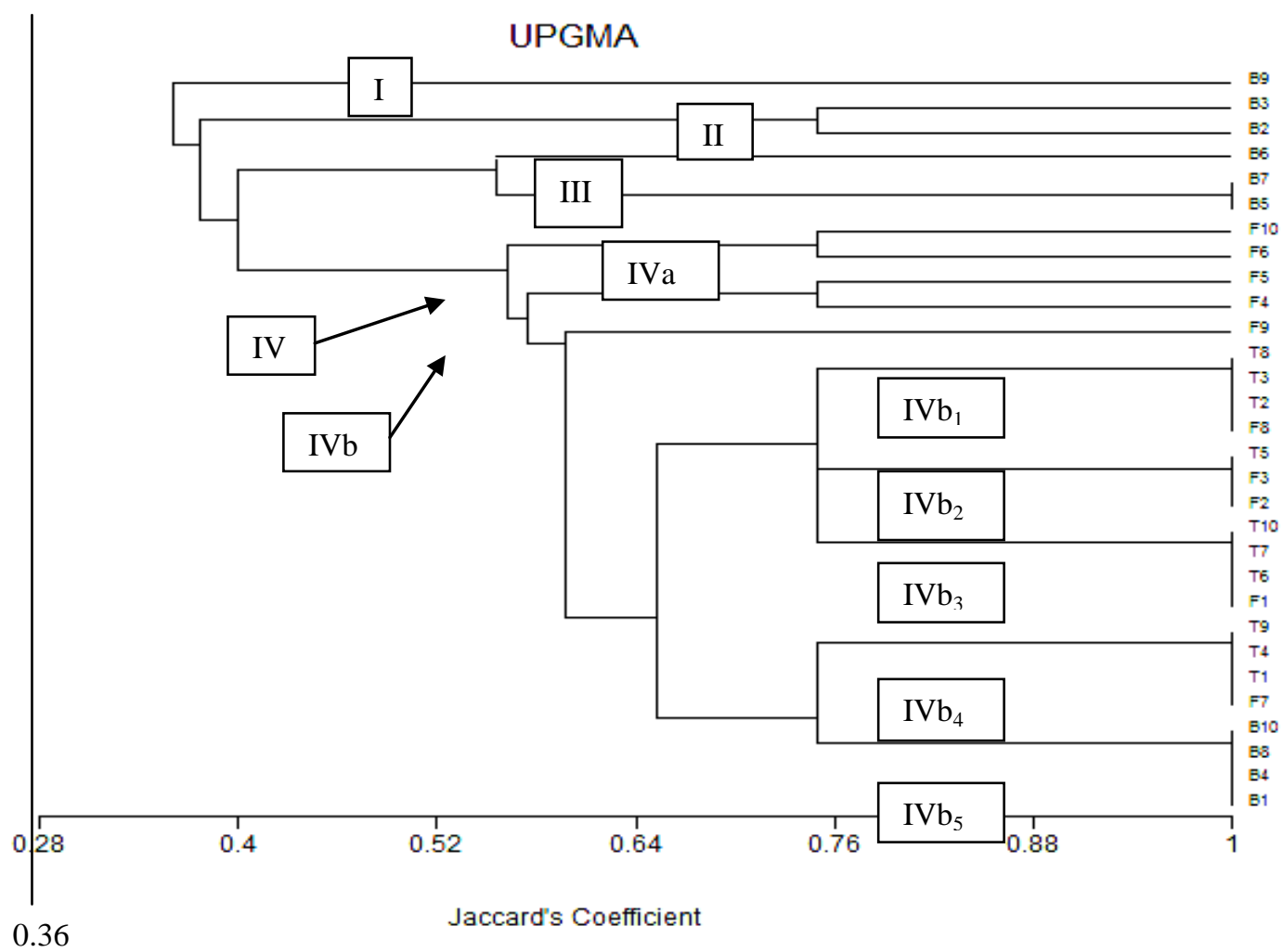

Gambar 2. Dendogram (kekerabatan fenetik) ketiga kultivar tomat Betavila F1, Fortuna F1 dan Tymoti F1 berdasarkan UPGMA dan Jaccard Coeficient. Kultivar Betavila F1 terdiri dari B1-B10, kultivar Fortuna F1 terdiri dari F1-F10 dan kultivar Tymoti F1 terdiri dari T1-T10 di lahan sama green house Situbondo. Indeks nilai persentase kesamaan antar kultivar ditunjukkan dengan garis tegak lurus menunjukkan nilai $0,36(36 \%)$.

\section{Simpulan dan Saran}

\section{Simpulan}

Berdasarkan pembahasan dendogram kekerabatan fenetik diatas, maka diketahui bahwa kultivar Fortuna F1 berkerabat dekat dengan kultivar Tymoti F1 dan kultivar Betavila F1 tidak membentuk hubungan kekerabatan fenetik karena memiliki karakter kualitatif yang tidak dimiliki oleh kultivar Fortuna F1 dan kultivar Tymoti F1.

\section{Saran}

Perlu dilakukan penelitian berikutnya dengan banyak karakter morfologi kualitatif lainnya dan anatomi tomat selain karakter data pengukuran untuk pembuatan kunci identifikasi.

\section{Daftar Pustaka}

Anonymous. 2006. Deskripsi Tomat Hibrida Varietas Fortuna. Keputusan Menteri Pertanian Nomor 345/Kpts/SR.120/5/2006. Jakarta.

Anonymous. 2011. Deskripsi Tomat Varietas Tymoti. Keputusan Menteri Pertanian Nomor 4276/Kpts/SR.120/10/2011. Jakarta.

Anonymous. 2015. Descriptor for Tomato (Lycopersicon spp.) (http://indoplasma.or.id/deskriptor/IPGRI/ deskriptor\%20tomat.pdf) Diakses 12/04/2015.

Anonymous. 2015. Varietas Betavila F1. (http://varitas.net/ dbvarietas/varimage/Tomat\%20Betavila.pdf) Diakses 31/08/2015.

Anonymous. 2015. Daftar warna. (http://silafi.fisika. unnes.ac.id/satria/www/kuliah/komputasi/Dafta r\%2 0warna.pdf) Diakses 19/10/2015.

Astari, W., Purwani, K.I. dan Anugerahani, W. 2014. Pengaruh Aplikasi Pupuk Hayati Terhadap Pertumbuhan dan Produktivitas Tanaman Tomat (Solanum lycopersicum L.) Var. Tombatu di PT Petrokimia Gresik. Jurnal Sains dan Seni Pomits, 2 (1): 2337-3520. 
Baihaki, A. 2000. Teknik Rancangan dan Analisis Penelitian Pemuliaan. Universitas Padjajaran. Bandung. $120 \mathrm{hlm}$.

Campbell, N.A., Reece, J.B., Urry, L.A., Cain, M.L., Wasserman, S.A., Minorky, P.V. dan Jackson, R.B. 2008. Biologi Edisi 8, Jilid 2. Erlangga. Jakarta. $101 \& 105$ hlm.

Dalirsefat, S.B., Meyer, A.D.S. dan Mirhoseini, S.Z. 2009. Comparison of Similarities Coefficients used for Cluster Analysis with Amplified Fragment lenght Polymorphism Markers in The Silkworm, Bombyx mori. Journal of Insect Science, 9: 1-8.

Darmawan. 2010. Karakterisasi Kromosom Tomat (Lycopersicon esculentum Mill.) Varietas Berlian dan Varietas Intan. Skripsi. Fakultas Sains dan Teknologi, Universitas Islam Negeri Sunan Kalijaga. Yogyakarta.

Donoghue, M.J. 2008. A Phylogenetic Perspective on The Distribution of Plant Diversity. Journal Proceedings of the National Academy of Sciences, 105: 11549-11555.

Hartati. 2000. Penampilan Genotip Tanaman Tomat (Lycopersicum esculentum Mill.) Hasil Mutasi Buatan Pada Kondisi Stress Air dan Kondisi Optimal. Jurnal Agrosains, 2(2):35-42.

Hasanah, U., Ardiansyah dan Rosidi, A. 2010. Pertumbuhan dan Evapotranspirasi Aktual Tanaman Tomat (Lycopersicum esculentum Mill.) Pada Berbagai Ukuran Agregat Inceptisols. The Agricultural Sciences Journal, 17 (1): 11-17.

Hasanuddin dan Fitriana. 2014. Hubungan Kekerabatan Fenetik 12 Spesies Anggota Familia Asteraceae. Jurnal EduBio Tropika, 2 (2): 187-250.

Hillis, D.M. 1987. Molecular Versus Morphological Approacges to Systematics. Annual Review of Ecology and Systematics 18: 23-42.

Maulida, I., Ambarwati, E., Nasrullah, dan Murti, R.H. 2013. Evaluasi Daya Hasil Galur Harapan Tomat (Solanum lycopersicum L.) Pada Musim Hujan dan Kemarau. Jurnal Vegetalika, 2 (3): 21-31.

Mustofa, Z., Budiarsa, I.M. dan Samdas, G.B.N. 2013. Variasi Genetik Jagung (Zea mays L.) Berdasarkan Karakter Fenotipik Tongkol Jagung yang Dibudidaya di Desa Jono Oge. Jurnal elektronik Prodi Biologi, 1: 33-41.

Nilahayati dan Putri, L.A.P. 2015. Evaluasi Keragaman Karakter Fenotipe beberapa Varietas Kedelai (Glycine max L.) di daerah Aceh Utara. Jurnal Floratek, 10: 36-45

Paran, I. dan Knaap, E.V.D. 2007. Genetic and Molecular Regulation of Fruit and Plant Domestification
Traits in Tomato and Pepper. Journal of Experimental Botany, 58 (14): 3841-852.

Purwati. 2009. Daya Hasil Tomat Hibrida (F1) di Dataran Medium. Journal of Horticultural, 19 (2): 125130 .

Putri, R.M., Adiwirman, dan Zuhry, E. 2014. Studi Pertumbuhan dan Daya Hasil Empat Galur Tomat (Lycopersicum esculentum Mill.) di Dataran Rendah. Jurnal Online Mahasiswa Fakultas Pertanian Universitas Riau, 1 (2): 1-9.

Rees, D., Farrell, G. dan Orchard, J. 2012. Crop PostHarvest: Science and Technology. Blackwell Publishing. Inggris. pp. 21

Sari, N. 2015. Keragaman dan Klasifikasi Intraspesies Ganyong (Canna indica $\quad$ L.) di Pulau Jawa Berdasarkan Karakter Morfologis dan Molekular. Tesis. Program Pascasarjana Fakultas Biologi, Universitas Gadjah Mada. Yogyakarta.

Soedomo. 2012. Uji Daya Hasil Lanjutan Tomat Hibrida di Dataran Tinggi Jawa Timur. Journal of Horticultural, 22 (1): 8-13.

Sofiari, E. dan Kirana, R. 2009. Analisis Pola Segregasi dan Distribusi Beberapa Karakter Cabai. Journal of Horticultural, 19 (3): 255-263.

Suratman, Priyanto, D. dan Setyawan, A.D. 2000. Analisis Keragaman Genus Ipomoea berdasarkan Karakter Morfologi. Jurnal Biodiversitas, 1 (2): 72-79.

Suryo. 2004. Genetika Strata 1 Cet. 10. Yogyakarta: Gajah Mada University Press. 8-9.

Visa, S., Cao, C., Gardener, B.M. dan Knaap, E.V.D. 2014 Modelling of Tomato Fruits Into Nine Shape Categories Using Elliptic Fourier Shape Modeling and Bayesian Classification of Countour Morphometric Data. Journal Euphytica, 200: 429-439.

Wahyuni, S., Yunianti, R., Syukur, M., Witono, J.K. dan Aisyah, S.I. 2014. Ketahanan 25 Genotipe Tomat (Solanum lycopersicum Mill.) Terhadap Pecah Buah dan Korelasinya dengan KarakterKarakter Lain. Jurnal Agronomi Indonesia, 42 (3): 195-202.

Wanda, N., Barmawi, M., Akin, H.M., dan Sa'diyah, N. 2014. Pola Segregasi Karakter Ketahanan tanaman Kedelai (Glycine max (L). Merrill) Terhadap Infeksi Soybean Mosaic Virus Populasi $\mathrm{F}_{2}$ Keturunan Taichung X Tanggamus. Jurnal Penelitian Pertanian Terapan, 15 (1): 54-60.

Wasonowati, C. 2011. Meningkatkan Pertumbuhan Tanaman Tomat (Lycopersicon esculentum) Dengan Sistem Budidaya Hidroponik. Jurnal Agrovigor 4 (1): $21-28$ 